\title{
Vascular injuries of the upper extremity
}

\author{
Lesões vasculares de membros superiores
}

\author{
Raafat Shalabi ${ }^{1}$, Yoysifh Al Amri', Elham khoujah ${ }^{3}$
}

\begin{abstract}
0 bjective: This study analyzes the causes of injuries, presentations, surgical approaches, outcome and complications of vascular trauma of the upper limbs, in spite of limited hospital resources.

Methods: A 5-year retrospective analysis. From 01/01/2001 to $31 / 12 / 2005,165$ patients were operated for vascular injuries at King Fahd Hospital, Medina, Saudi Arabia. Of all peripheral vascular trauma patients (115), upper limb trauma was present in 58. D iagnosis was made by physical examination and hand-held D oppler al one or in combination with D oppler scan/angiography. Primary vascular repair was performed whenever possible; otherwise, the interposition vein graft was used. Fasciotomy was considered when required. Patients with unsalvageable lower extremity injury requiring primary amputation were excluded from the study.

Results: Fifty patients were male (86\%) and eight were female (14\%), aged between 2.5-55 years (mean 23 years). M ean duration of presentation was $8 \mathrm{~h}$ after the injury. The most common etiological factor was road traffic accidents, accounting for $50.5 \%$ in the blunt trauma group and $33 \%$ among all penetrating and stab wound injuries. Incidence of concomitant orthopedic injuries was very high in our study $(51 \%)$. The brachial artery was the most affected (51\%). Interposition vein grafts were used in $53 \%$ of the cases. Limb salvage rate was $100 \%$.

Conclusion: Patients who suffer vascular injuries of the upper extremities should be transferred to vascular surgery centers as soon as possible. D ecisive management of peripheral vascular trauma will maximize patient survival and limb salvage. Priorities must be established in the management of associated injuries, and delay must be avoided when ischemic changes are present.
\end{abstract}

Keywords: Vascular trauma, upper extremity, vein interposition.

1. MD. Consultant in Vascular Surgery, King Fhad Hospital, Medina Mounwara, Saudi Arabia.

2. MD. Consultant in Causality and Orthopedic Surgery, King Fhad Hospital, Medina Mounwara, Saudi Arabia.

3. MD, Consultant in Vascular Surgery, King Fhad Hospital, Medina Mounwara, Saudi Arabia.

Artigo submetido em 13.11.06, aceito em 27.12.06.

J Vasc Bras 2006;5(4):271-6.

Copyright $\odot 2006$ by Sociedade Brasileira de Angiologia e de Cirurgia Vascular.

\section{Resumo}

O bjetivo: Este estudo analisa as causas de lesões, apresentação, abordagens cirúrgicas, deffechos e complicações do trauma vascular de membros superiores, apesar de recursos hospitalares limitados.

M étodos: Análise retrospectiva de 5 anos. D e 01/01/2001 a 31/ 12/2005, 165 pacientes foram operados devido a lesões vasculares no King Fahd $\mathrm{H}$ ospital, M edina, Arábia Saudita. D e todos os pacientes com trauma vascular periférico (115), trauma de membros superiores esteve presente em 58. 0 diagnóstico foi realizado por exame físico e D oppler manual isoladamente ou associado com ultra-som D oppler/ angiografia. A restauração vascular primária foi realizada sempre que possível; do contrário, utilizou-se a interposição de veia. A fasciotomia foi considerada quando necessário. Pacientes com lesão de membro inferior não resgatável necessitando de amputação foram excluídos do estudo.

Resultados: Cinqüenta pacientes eram homens ( $86 \%$ ) eoito eram mulheres (14\%), com idade entre 2,5 e 55 anos (média de 23 anos). A duração média de apresentação foi $8 \mathrm{~h}$ pós-lesão. 0 fator etiológico mais comum foi acidente em estradas, sendo responsável por $50,5 \%$ no grupo de trauma contuso e 33\% entre as lesões penetrantes e por arma branca. A incidência de lesões ortopédicas concomitantes foi muito alta em nosso estudo (51\%). A artéria braquial foi a mais afetada (51\%). A interposição de veias foi utilizada em $53 \%$ dos casos. A taxa de preservação de membros foi de $100 \%$.

Conclusão: Pacientes que sofrem lesões vasculares de membros superiores devem ser transferidos para centros de cirurgia vascular 0 mais rápido possível. 0 tratamento imediato do trauma vascular periférico aumentará a sobrevida dos pacientes e a preservação dos membros. D evem-se estabelecer prioridades no tratamento de lesões associadas e evitar 0 atraso quando alterações isquêmicas estiverem presentes.

Palavras-chave: Trauma vascular, membro superior, interposição de veia.

\section{Introduction}

Vascular injury is a major complication of military and civilian trauma. M ajor developments in this field have been related to military conflicts during the past 100 years. $^{1}$

Trauma has become a public health problem in many parts of the world, and vascular trauma is an important component of this problem. ${ }^{2}$ In the USA, 
themajority of upper extremity vascular injuriesaredue to penetrating trauma, with progressively increasing numbersattributableto iatrogenic causes. Blunt injuries account for $6-10 \%$ of upper extremity vascular trauma and are often associated with musculoskeletal injuries and neural injuries. ${ }^{3}$

H owever, the mechanism of injury seems to differ between different parts of theworld. 4,5 W hilesuccesful treatment of major arterial injuriesmay belife-saving as well asallowing limb salvageand restoration of function, ${ }^{6}$ return of function is often related to the presence of concomitant injury to peripheral nerves. ${ }^{3}$

U pper limb vascular trauma can therefore be associated with major morbidity and mortality, but littleisknown about itsincidence or naturein M edina, Saudi Arabia. A retrospective study of 58 patients requiring operativeintervention for upper limb vascular trauma over a 5-year period between 01/01/2001 and $31 / 12 / 2005$ was performed. In this report we present the different mechanisms of trauma, arteries involved, associated orthopedic or nerve injuries and types of vascular repairsemployed. T o thebest of our knowledge, this is the first report on upper limb vascular trauma from this region of Saudi Arabia, which is highly respectable to all M uslims worldwide.

\section{Patients and methods}

During the 5-year period, 58 patients presented with upper extremity vascular injuries at King Fahd H ospital, M edina, Saudi Arabia. All patientsunderwent full physical examination and resuscitation according to the principles of the advanced trauma and life support (AT LS) guidelines. The patients were either first assessed by emergency room residents or were referred from the orthopedic surgeon after finding absent distal pulsesin apatient with fractureor fracture/ dislocation of the extremity (Figures 1 and 2 ).

The diagnosis of an upper extremity vascular injury is initially made by physical examination as part of the full trauma assessment. The classic fiveP's - pain, pulsel essness, pallor, paresthesias, and paralysis - may be partially present or may be absent in many patients. Some patients with axillary and proximal brachial artery injuries may have palpable pulses at thewrist. Theinjury typeand location arenoted, and the axillary, brachial, radial, and ulnar arteries are palpated for pulsations. D epending on the mode of presentation, most patients were taken immediately

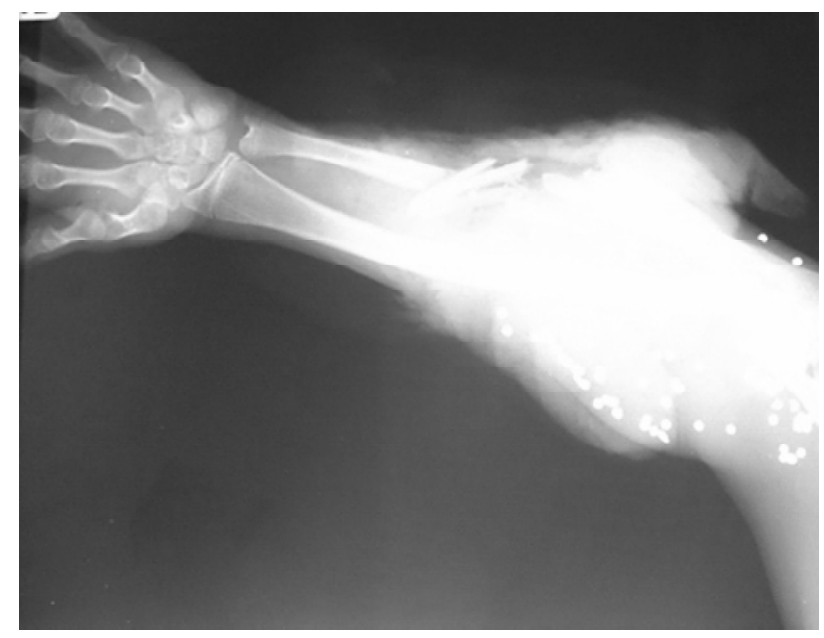

Figure 1 - X-ray of massive bone fracture (gun missiles)

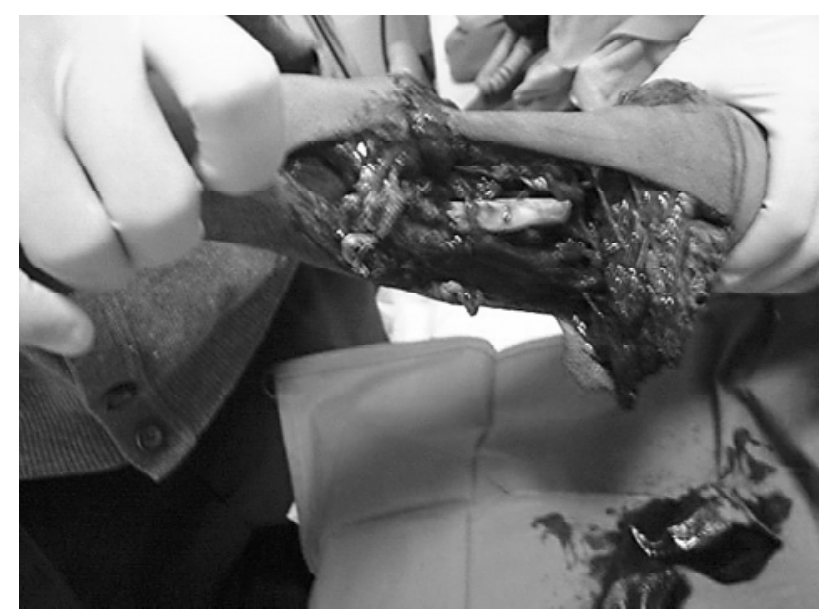

Figure 2 - M assive musculoskeletal trauma

to the operating room for vascular or orthopedic/ vascular management. In others with soft signs or doubtful vascular injury (especially with hematoma, compartmented limb or for medico-legal reasons) and when patients were stable, preoperative duplex ultrasonography/angiography were performed (Figure 3).

All patients with associated orthopedic injury underwent reduction of joint dislocation or bonefracture and immobilization by internal or external fixation (Figure 4).

It always preceded vascular repair unless the extremity was threatened and required immediate revascularization. Endoluminal shuntswere not used in any patient. Patients with more severe soft tissue 
and muscle injuries were treated with thorough debridement of all grossly nonviable tissue, with removal of foreign bodies and copious irrigation with isotonic saline performed by us and the orthopedic surgeons (Figure 5). Suitable covers for the defect were developed by plastic surgeons with split-skin grafting or with the application of flap techniques.

Repaired vessels, especially at the anastomotic suture lines and graft location, were compulsory covered with muscles and soft tissue to prevent desiccation and disruption. In all patients, management of vascular injuries was performed in the operating room under general anesthesia using standard vascular techniques. D epending on the condition of the limb after revascularization, open full fasciotomy was carried out liberally to either relieve existing compression or to avoid one from occurring in the postoperative period (Figure 6).

Fasciotomy wounds were usually covered later by a delayed primary, split-thickness skin graft (Figure 7).

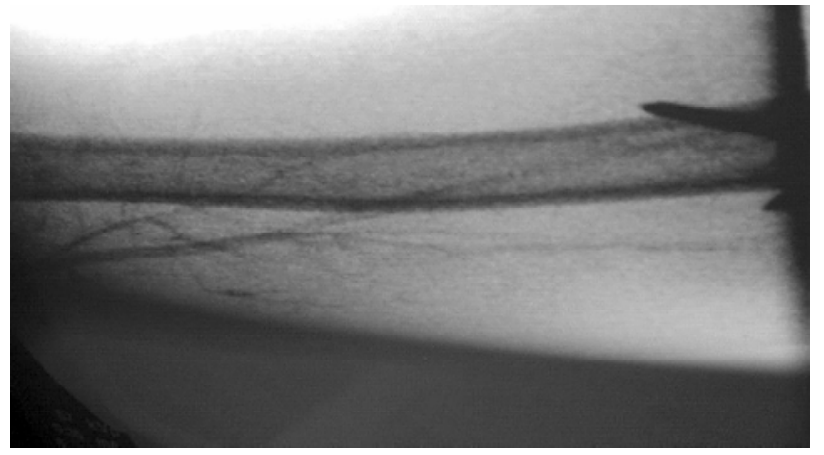

Figure 3 - Preoperativeangiography, supracondylarfracture



Figure 4 - Pre-revascularization bone fixation
An intraoperative angiogram was performed in few cases, whenever distal pulses were absent after therevascularization or assessing injury siteor spasm.

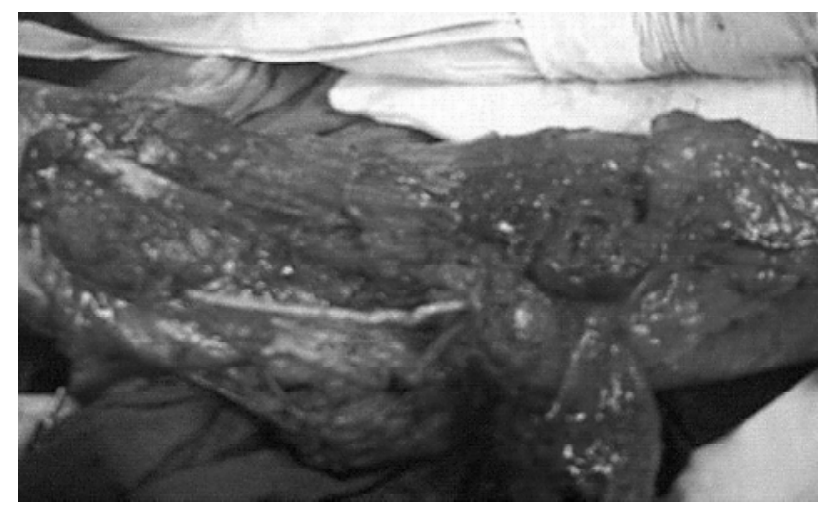

Figure 5 - Crushed brachial artery revascularization (saphenous vein conduit)

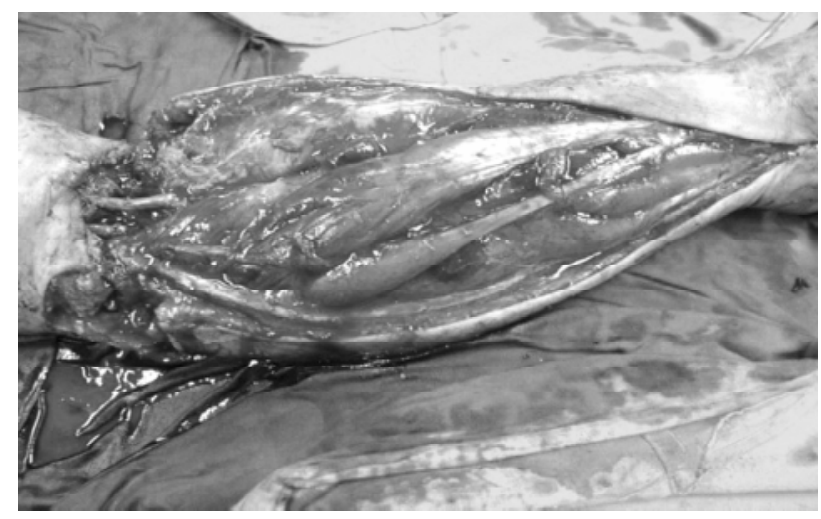

Figure 6 - Fasciotomy after brachial artery repair

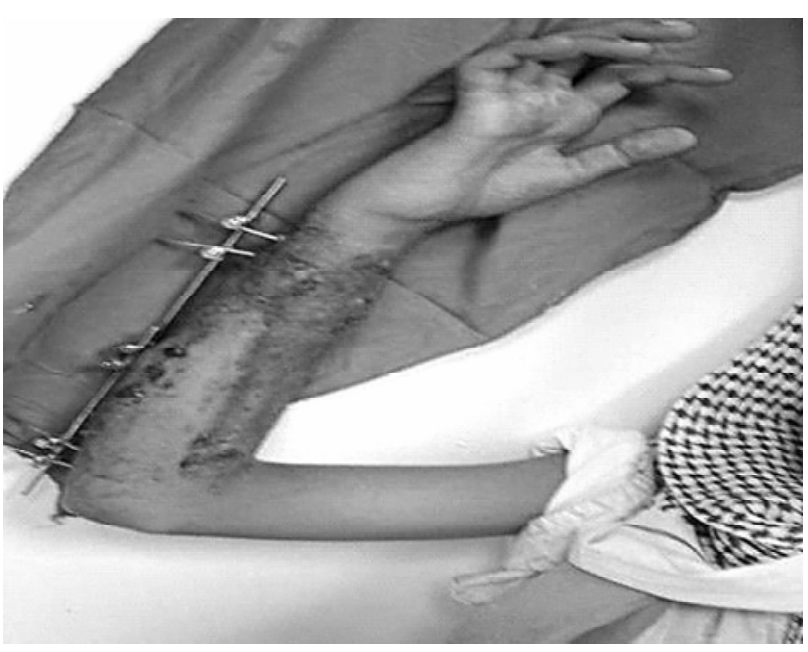

Figure 7 - D elayed primary, split-thickness skin graft 
Successful repair was assessed by the return of distal pulses at the end of the operation. Although associated nerve injuries were not usually repaired at the time of vascular repair, major associated venous injuries were repaired whenever possible, in an attempt to prevent postoperative venous hypertension and to minimize development of compartment syndrome. Patients with unrepaired nerveinjurieswerepostoperatively followed by our colleagues in neurosurgery. Four weeks after hospital discharge, patients were routinely examined in the outpatient department (OPD) to assess functional status of the limb. Thereafter, they were followed at longer periods of time. All patientsreceived intravenous preoperative prophylactic antibiotics, which were continued postoperatively for 5 to 7 days, unless prolonged use was dictated by the presence of contamination or infection, or else advised by the attending orthopedic/plastic surgeons. All patientsalso received intravenous heparin for a period of 5-7 days postoperatively and were discharged home on oral aspirin $100 \mathrm{mg}$ tablet/day for a period of 12 weeks.

Patients with isolated venous trauma and patients with unsalvageable lower extremity injury requiring primary amputation were excluded from the study.

\section{Results}

Successful outcome in vascular trauma depends on early diagnosis and referral to specialists. In our series, most patients presented what is considered as the "golden period." The time interval between the beginning of the trauma and arrival to our center was $8 \mathrm{~h}$ in average.

The patients consisted of 50 males (86\%) and eight females ( $14 \%$ ) with mean age of 23 years (range 2.5-55 years). The left and right upper limbs were equally involved in 39 patients (50\%). The mechanism of trauma was blunt in 39 patients $(67 \%)$ and penetrating in the remaining 19 patients (33\%). H owever, road traffic accident (RTA) was the most common cause of upper limb vascular injury in this group of patients, occurring in 35 patients $(52.5 \%)$. Stab injury wasthe most frequent form of penetrating trauma (11 out of 19). O ther forms of trauma in a descending order of frequency were cut wrist in four patients $(7 \%)$, industrial or machinery such as electric saw or hand drilling machinein two patients $(3.5 \%)$, gunshot in three patients (5\%) and fall to the ground in six patients (10\%).
Thirty patients (51\%) presented with ischemia, 20 patientswith bleeding (34\%) and eight with hematoma $(13.5 \%)$.

Thebrachial artery wasthemost frequently affected (30 patients, $51 \%$ ), followed by the ulnar artery alone in threepatients $(5 \%)$, both theulnar and radial arteries in 12 patients $(20.5 \%)$ and the radial artery alone in seven patients (12\%). The axillary artery was involved in five patients $(8.5 \%)$, and the subclavian arteries in one patient (1.7\%).

The vascular injury wasmore often associated with orthopedic injuries (30 patients, 51\%). O rthopedic injurieswerein theform of supracondylar fracturein 13 patients $(21 \%)$, fracture/dislocation in seven patients $(12 \%)$ and dislocation al one in seven patients (12\%).

Concomitant vein or nerve injury al so occurred in 35 patients $(59.5 \%)$. Associated nerve injury occurred in 13 patients (22\%), vein injury in 22 patients(37.5\%) and both occurred in 15 patients $(22.5 \%)$.

In 50 patients ( $86 \%$ ) the diagnosis of arterial injury was based on clinical and hand-held Doppler examination. Preoperative angiography was used in two patients $(3.5 \%)$. D uplex scan was used in only 10 patients (17\%).

Arterial repair performed by interposition vein graft in 31 patients (53\%) was the most frequently used single technique of arterial repair. 0 ther techniques used were ligation in 10 patients (17\%); primary anastomosis by end-to-end anastomosis in 17 patients (29\%). V enous bypass grafting was used in onepatient (1.7\%). R epair of major venousinjuries was performed in two patients $(3.5 \%)$. Therapeutic or prophylactic fasciotomy was performed in nine patients (15\%).

$\mathrm{N}$ o patient underwent amputation and no onedied as a consequence of upper limb vascular injury. A limb salvage rate of $100 \%$ was therefore achieved.

\section{Discussion}

C are of the patient with an injured arm begins at the scene of injury, especially if there is an associated vascular injury. Knowledge of the time of injury and rapid transportation from the scene of injury to a suitable facility are also critical in the early management of thesepatients. ${ }^{3}$ Therefore, aspecialist vascular surgeon should havetheparticular specialized surgical skills, techniques and materials for the care of such patients. ${ }^{7}$ 
Specific surgical techniques ${ }^{8}$ must be mastered if successful vascular repair isto beachieved. Theseinclude proximal and distal exposure for control with vascular clamps and loops; dissection and isolation of injured vessels including veins; local and/or systemic heparinization; use of vascular sutures; magnification loops; assessment of injury: debridement, contusion, intimal flap and distal dissection and thrombosis; selective use of shunting; anatomic repairs, with vein patch, end/end anastomosiswithout tension and reversed autologousvein graft for larger defects; technical details of spatulated ends, running vs. interrupted sutures; distal thrombectomy; ${ }^{9}$ completion arteriography; ${ }^{10}$ fasciotomy and soft tissue coverage. Proper handling of the autogenous vein graft is important. 11

The timing of the vascular repair in relation to fracture management has long been a source of controversy. The standard recommendation is for vascular repair to precede orthopedic management. Prevention of prolonged tissueischemiaistheobjective. W hile there are no prospective studies, $\mathrm{M} \mathrm{CH}$ enry, ${ }^{12}$ in a retrospective study, suggested an increased need for fasciotomy when fractures are stabilized before revascularization. N o cases of disruption of vascular repair occurred in 22 cases of subsequent fracture stabilization. M ost fracturescan beadequately stabilized with traction or posterior plaster splinting, but external fixation may be necessary in some cases. Volgas ${ }^{13}$ gives a good review of ballistic injury management.

Imaging, in particular contrast arteriography, has played an important rolein the devel opment of vascular surgery. While it is clear that advanced imaging techniques are important in the management of zones 1 and 3 neck injuries ${ }^{14}$ and thoracic aortic disruption ${ }^{15}$, for most extremity vascular injuries preoperative arteriography is not necessary. H owever, on-table operative angiograms are easily carried out with a minimum amount of equipment and provideimportant information about theextent of injury and theadequacy of repair. ${ }^{10}$ In suspected vascular injury exclusion, arteriography has been shown to be cost-effective. ${ }^{16}$ Theliteratureisfull of epidemiological studiesdescribing thefeatures of vascular traumain variouscountries. ${ }^{17-25}$ There is wide variation in the incidence, cause and mechanism of injury, depending on thelocal conditions. In acivilian population in Australia21,25, vascular injuries represent $1-2 \%$ of total trauma patients. $\mathrm{H}$ owever, they account for $20 \%$ of all trauma-related death. ${ }^{21} \mathrm{D}$ eaths from vascular injury vary considerably with anatomical location and mechanism of injury. Thoracic and abdominal injuries routinely have death rates between 30-50\%; vascular injuriesto extremitiesaresignificantly lower in the range of $5 \%$. In an unparalleled largestudy in V ietnam, Rich ${ }^{26}$ reported a total death of only $1.7 \%$ for all vascular injuries. It may be that life-threatening vascular injuries were preselected by their failure to survivetransportation. In thecurrent warfareconditions of theAmerican intervention in I raq and Afghanistan 27 , vascular trauma represents $7 \%$ of total battle injuries, $88 \%$ of these were extremity injuries. The amputation rate was only $8 \%$ after vascular repair.

In North India, ${ }^{19}$ with a low risk of personal violence, blunt injuries, mostly motor vehicleaccidents, account for $84 \%$ of vascular injuries. Whereas in M edellin, Colombia, 22 93\% of vascular injuries are penetrating and in $\mathrm{G}$ eorgia ${ }^{18}$ they represent $85 \%$ of the total. Surprisingly, in theE uropean experience, ${ }^{24}$ up to $40 \%$ of vascular injuries are iatrogenic, as a result of vascular and other surgical interventions. Kuwait 17 strikes a middle ground with $41 \%$ penetrating, $23 \%$ a result of RT A and $22 \%$ iatrogenic. In M alaysia, ${ }^{20}$ over $50 \%$ of vascular injuries occur as a result of RTA.

As far as anatomic site of injury is concerned, variability is less. In Australia 21,25 , injuries are split almost equally between thorax, abdomen and upper and lower extremities, with cervical injuries being less common. In Latin America, ${ }^{23}$ extremity injuries are twice as common as thoracic and abdominal, although theselater result in higher mortal ity. Asfar asextremities are concerned, upper and lower injuries occur with similar frequency and thebrachial, femoral and popliteal arteries are the most commonly injured vessels. With special relevance to conditions in Africa, in the Latin American survey, $2368 \%$ of cases were managed on a clinical basis alone, i.e., without arteriography, and $78 \%$ were managed within $6 \mathrm{~h}$ of injury.

Among other findings, this study showed that themain victims of upper limb vascular injury in this region are males, with female patients forming $14 \%$ of the total.

RTA was the commonest single mechanism of trauma $(52.5 \%)$ in this study, mostly in male patients. Thismay bedueto thefact that theroad traffic isintense during Umra and $\mathrm{H}$ ajj period and when visiting the $M$ osque of prophet $M$ ohamed, leading $M$ edina to have one of the highest rates of RT A in Saudi Arabia. Also, women are not allowed to drive. 
Thebrachial artery wasthemost frequently affected artery in our patients at a rate of $51 \%$, which is in agreement with most previous reports of between 37$66 \%$. The most frequent type of vascular repair was interposition vein graft, using thethigh long saphenous vein, at a rate of $53 \%$. Intraluminal shunts were not used in any of our patients without adverse effect, this agreed with Wally. Fasciotomy is especially recommended in cases of established ischemia, as previously pointed out by Fletcher \& Little. No amputation performed in this series compared with reportsfrom W ally (4\%), Brown et al. (6\%) and K ruseAndersen et al. (28\%). ${ }^{2}$

Thefunctional outcomedepended on theassociated nerve injuries as previously pointed out by different authors. ${ }^{2} \mathrm{~N}$ o mortality was reported in our patients.

\section{Conclusion}

Prompt vascular repair of the upper extremity and attention to associated injuries result in a minimum morbidity and zero mortality. I n our study, we dealt with vascular injuries and associated problemsin onesession and thesepatientsperformed very well in the follow-up.

Increasing number of religious tourists, especially in our region (M edina $M$ ounwara), has resulted in increasing number of RTA, higher than stab or penetrating trauma.

\section{References}

1. $H$ ood D B, Y ellin AE, W eaver F. V ascular trauma. In: $D$ ean $R H$, YaoJST, Brewster D C, editors. C urrent diagnosis\& T reatment in Vascular surgery. Connecticut: Lange; 2000. p. 405-28.

2. Wali MA. U pper limb vascular trauma in the Asir region of Saudi Arabia. Ann Thorac Cardiovasc Surg. 2002;8:298-301.

3. H unt CA, K ingsleyJR. Vascular injuries of theupper extremity. South M ed J. 2000;93:466-8.

4. Creagh TA, Broe PJ, Grace PA, Bouchier-H ayes DJ. Blunt trauma-induced upper extremity vascular injuries. J R Coll Surg Edinb. 1991;36:158-60.

5. Shaw BA, Kasser JR, Emans JB, Rand FF. M anagement of vascular injuries in displaced supracondylar humerus fractures without arteriography. J O rthop T rauma. 1990;4:25-9.

6. Kruse-Andersen S, Lorentzen JE, Rohr N . Arterial injuries of the upper extremities. Acta Chir Scand. 1983;149:473-7.

7. I rizE, Kolbakir F, Sarac A, Akar H , K eceligil H T, D emirag M K. Retrospective assessment of vascular injuries: 23 years of experience. Ann Thorac Cardiovasc Surg. 2004;10:373-8.

8. Rutherford RB. Basic vascular surgical techniques. In: Rutherford RB, editor. V ascular surgery. Philadel phia: W B Saunders; 2004. p. 395-404.
9. Fogarty $\mathrm{TJ}$. Fogarty catheter thrombectomy. In: Rutherford RB, editor. V ascular surgery. Philadel phia: W B Saunders; 2004. p. 410-4.

10. Subber SW . Contrast arteriography (excerpt). In: Rutherford RB, editor. V ascular surgery. Philadel phia: W B Saunders; 2004. p. 195-202.

11. T owne JG. The autogenous vein. In: Rutherford RB, editor. V ascular surgery. Philadel phia: W B Saunders; 2004. p. 482-91.

12. $\mathrm{M}$ CH enry TP, H olcomb JB, Aoki N , Lindsey RW. Fractures with major vascular injuriesfrom gunshot wounds: implications of surgical sequence. J Trauma. 2002;53:717-21.

13. Volgas DA, Stannard JP, Alonso JE. Current orthopaedic treatment of ballistic injuries. Injury. 2005;36:380-6.

14. Ferguson E, D ennis JW, Vu JH, Frykberg ER. Redefining the role of arterial imaging in the management of penetrating zone 3 neck injuries. Vascular. 2005;13:158-63.

15. Blackmore CC, Zweibel A, M ann FA. Determining risk of traumatic aortic injury: how to optimize imaging strategy. AJR Am J Roentgenol. 2000;174:343-7.

16. Keen JD, Keen RR. The cost-effectiveness of exclusion arteriography in extremity trauma. Cardiovasc Surg. 2001;9: 441-7.

17. Asfar S, Al-Ali J, Safar H , et al. 155 vascularinjuries: aretrospective study in Kuwait, 1992-2000. Eur J Surg. 2002;168:626-30.

18. Razmadze A. Vascular injuries of the limbs: a fifteen-year Georgian experience. Eur J Vasc Endovasc Surg. 1999;18: 235-9.

19. M enakuru SR, Behera A, Jindal R, Kaman L, Doley R, $V$ enkatesan $R$. Extremity vascular trauma in civilian population: a seven-year review from N orth India. Injury. 2005;36:400-6.

20. Lakhwani MN, Gooi BH, Barras CD. Vascular trauma in Penang and Kuala Lumpur Hospitals. M ed J Malaysia. 2002;57:426-32.

21. Sugrue M, C aldwell EM , D amours SK, C rozier JA, D eane SA. Vascular injury in Australia. Surg Clin N orth Am. 2002;82: 211-9.

22. $M$ orales- $U$ ribe $C H$, Sanabria-Q uiroga $A E$, Sierra-J ones JM . Vascular trauma in Colombia: experience of a level I trauma center in M edellin. Surg Clin N orth Am. 2002;82:195-210.

23. Sonneborn $R$, Andrade $R$, Bello $F$, et al. Vascular trauma in Latin America: a regional survey. SurgC lin N orth Am. 2002;82: 189-94.

24. Fingerhut $A$, Leppaniemi AK, Androulakis $G A$, et al. The European experience with vascular injuries. Surg $C$ lin N orth Am. 2002;82:175-88.

25. Gupta R, Rao S, Sieunarine K. An epidemiological view of vascular trauma in Western Australia: a 5-year study. AN Z J Surg. 2001;71:461-6.

26. Rich N M . C omplications of vascular injury management. Surg Clin N orth Am. 2002;82:143-74.

27. Fox CJ, Gillespie DL, O 'D onnell SD, et al. Contemporary management of wartimevascular trauma. J V asc Surg. 2005;41: 638-44.

\section{Correspondence:}

Raafat Shalabi

King Fhad H ospital, M edina M ounwara, Saudi Arabia

Phone: +9664846150s0 / 3219, +966506319117

Fax: +96648461190

E-mail: raafatshalabi@hotmail.com 